Article

\title{
When a Fire Starts to Burn. The Relation Between an (Inter)nationally Oriented Incinerator Capacity and the Port Cities' Local Circular Ambitions
}

\author{
Karel Van den Berghe ${ }^{1,2, *(\mathbb{D})}$, Felipe Bucci Ancapi ${ }^{1}$ and Ellen van Bueren ${ }^{1}$ \\ 1 Department of Management in the Built Environment, Delft University of Technology, \\ 2628 BL Delft, The Netherlands; F.E.BucciAncapi@TUDelft.nl (F.B.A.); E.M.vanBueren@TUDelft.nl (E.v.B.) \\ 2 Department of Geography, Ghent University, Krijgslaan 281, 9000 Gent, Belgium \\ * Correspondence: K.B.J.VandenBerghe@TUDelft.nl; Tel.: +31-(0)1-5278-4159
}

Received: 29 May 2020; Accepted: 12 June 2020; Published: 15 June 2020

check for updates

\begin{abstract}
This paper assesses the potential of the circular economy (CE) policy ambitions of the port cities of Ghent (Belgium) and Amsterdam (The Netherlands). Both Ghent and Amsterdam are municipalities that potentially lend themselves ideally to set up a more local-oriented circular (re)production and (re)consumption system. Subsequently, both have the ambition that, in 2050, the $\mathrm{CE}$ will have become an achieved public value that influences all activities to be more circular in comparison with today. However, while having ambitious policies is important, we explain that a public value also requires alignment with the operational capacity used or needed to achieve this policy ambition. In this paper, we focus on the 'negative' CE operational capacity: landfills and incinerators. Our results show that the $\mathrm{CE}$ ambitions of Ghent are more realistic than Amsterdam. During the last few decades, Dutch waste management has been largely privatized. This led to a significant increase in incinerator capacity and a lowering of the incineration price. This differs from Flanders, which has a deliberate capping on the allowed incinerator capacity, keeping the price for incineration high. This increases the incentive for urban and maritime actors to climb the waste hierarchy, eventually thus making the port city (potentially) more circular as a whole.
\end{abstract}

Keywords: circular economy; port cities; public value; strategic management; incinerator capacity

\section{Introduction}

This paper assesses the potential of the circular economy (CE) policy ambitions of port cities, specifically, the policy ambitions of their urban and their port authorities. To do so, it, however, does not focus primarily on port cities, but on the institutional and socioeconomic structures they are part of. We do this to avoid a bias towards success, in geography also known as the so-called 'territorial trap.' Hereby, the outcome of the research is being predefined by the idealizing of a given territorial bordered object [1]. Originally, the territorial trap was developed during the dawn of the post-cold war globalization to criticize research using territorial variables to explain the (non-) success of states to accommodate international businesses without focussing on the business itself or take into account international relations that would shape territorial spaces [2]. Arguably, to assess the (non-) success of the CE, the 'danger' of the bias towards success is relevant (again). Although the CE is a relatively new concept, it has experienced an enormous hype among public and private actors $[3,4]$. The $\mathrm{CE}$ is increasingly seen as one of the key strategic societal goals towards sustainable development [5]. While being a strategic goal in China since the late 1990s [6], more recently it has been adopted by the United Nations [7], the Organisation for Economic Co-Operation and Development (OECD) [8] and the European Union $[9,10]$ among others. Within Europe, both Belgium (for this paper we focus 
on the region of Flanders) [11] and The Netherlands [12] have set the ambition to become fully circular in 2050. All of these policies are, however, arguably difficult to assess, as they all in essence are the same: having a full CE in 2050. Said otherwise, only in 2050 will we be able to assess the (non-) success of the policies and their ambitions today. Therefore, to make it more concrete, policy reports or research, e.g., [13], focus on best practices to assess the results of CE policy ambitions [14]. However, a recent study in The Netherlands revealed that the best practices of CE innovations only represent a very small amount of the total amount of CE innovations. The vast majority innovate the highest recycling activities but no higher R-steps of the waste prevention hierarchy $[15,16]$. This is a concern, as in reality, the world is increasingly less circular [17]. Today, $8.6 \%$ is circular of all materials (around 100 billion tonnes) used per year, down from $9.1 \%$ two years ago because of an increase of extraction, the build-up of material stocks, and low levels of end-of-use processing and cycling [18].

Here lies the territorial trap of the CE, whereby a conceptual error occurs regarding region or cities as fixed units or containers, separated from outside political and socioeconomic spaces. If, then, the (non-) success of circular policies of these spaces is used, the results are predefined (cf. [19]). As such, the more or less amount of successful CE stories defines then how a government is performing, (implicitly), thus favouring individual (mostly subsidized) efforts instead of more overall adjustments regarding the $\mathrm{CE}$. This makes it also difficult to objectively compare administrative areas regarding their efforts to strive towards a CE. Moreover, as agenda-setting theories have pointed out [20], as such, the uncritical discourse of circular success stories can even be used by policy actors as a strategy to push particular agendas to the front at the expense of others [21,22].

In this paper, the research objective was to assess the (potential) success of circular policy ambitions without focusing on the (successful) projects themselves. Our hypothesis was that focussing on success stories blurs our understanding of the actual situation of the CE of a certain region or city. Therefore, in contrast, we assessed circular policy ambitions by analysing what their potential is to effectively let the CE emerge as a public value. Thus, to become more circular, in comparison with the current situation, this requires influencing all activities and not only creating a few success stories within or linked to the administrative responsible area or structure [23]. Our focus is on the lowest administrative level, namely, the municipal level. In particular, we focus on port cities, municipalities characterized by an economy centring on knowledge and industrial logistical economy [24]. We focus on these, because our proposition is that they have particular contexts that potentially lend themselves better to adapt (more) a CE. Next, to avoiding the use of primary materials, it is assumed that the $\mathrm{CE}$ also will strive towards a (re)production and (re)consumption system or paradigm [25] that remains as local as possible [26,27]. Therefore, if successful, the CE will most likely be characterized by a 'glocal' system [28], whereby global (re)production networks will keep on existing [29,30], but with a more (sustainable) balance departing from the local level. What is more, translating the CE of 2050 back to the policy choices today, urban regions having the space for and/or are already hosting industrial (re)production or logistical functions, have a higher potential to adapt to a CE in comparison with urban regions which, today, do not have the space and/or industrial (re)production or logistical functions. The assumption here is that existing residential, agricultural, or nature land use will not (all) be transformed into industrial land use. However, this is of course only the CE potential of matching (re)production and (re)consumption, understood in geographical economic terms. In a reciprocal way, this is also the opportunistic reason why many port cities' authorities, the local and the port authorities, put the CE as their central competitive ambition and are trying to let the CE emerge as a public value that defines all activities within, towards, and from their urban/maritime economies. However, in spatial terms, as described by Van den Berghe and Vos [22], the CE ambitions of the local authorities and the port authorities can conflict within the same port city. In Amsterdam, currently a land use conflict exists between port and city to transform an existing maritime area into a residential area, although both use the discourse of circularity to claim their 'right' on that particular area. The urban government links circularity to the built environment, stating that all new built buildings will be circular, consequently helping to achieve its $\mathrm{CE}$ ambitions. The port authorities link circularity to 
(re)production processes and the need of such functions to be located as close as possible to the city [22]. In other words, the higher potential of port cities to adapt to a $\mathrm{CE}$, understood in geographical economic terms, is not (always) the same perspective on CE from some policy-makers within port cities.

The remaining of this paper is as follows. First, we will introduce the concept of public value and how it is constituted by its legitimacy and operational capacity. Legitimacy is understood as the legal and policy context, while the operational capacity is understood in this paper as the industrial/physical production capacity. The public value concept lends itself ideally to assess how the circular policy ambitions (legitimacy) are aligned or not with the existing operational capacity. In other words, as such, we are able to link policy of the CE with the economic/technical side of the CE, two 'parts of the $\mathrm{CE}^{\prime}$ that are mostly not linked to each other [25]. The (non-) alignment between the two then informs us of the potential of the policy ambitions to let the CE emerge as a public value, eventually thus influencing all activities to become more circular. The third section explains our operational framework. In our results, we map the legitimacy and support, or the circular policies and their ambitions, and the operational capacity of the CE. As we will explain, we assess the latter by looking at the 'negative' CE operational capacity, or the operational capacity of incinerators in Flanders (Ghent) and The Netherlands (Amsterdam). In our discussion, we will show how in Flanders the local-to-regional CE ambitions are better aligned with the operational capacity of the $\mathrm{CE}$, while in The Netherlands a lock-in is created that hinders a CE that is able to go beyond the incineration or recover level. Based on our results, we conclude with policy recommendations towards the local and regional strategic CE management of the port cities of Ghent and Amsterdam.

\section{The Circular Economy as Public Value}

\subsection{The Public Value Concept}

The public value concept was coined by Moore [31] and is an organizing principle focusing originally on public sector organizations but has become more widely used. Public value describes the value that an organization contributes to the society. It can be the result from improving the government itself as an asset to society, or it can be the result from the delivery of specific benefits to the people. Moore saw public value as the equivalent of the shareholder value sought by the private sector, whereby public organizations seek public value, rewarded in an arguably similar way as pursuing shareholder value. Moore used public value as a 'counterweight' for the then widely applied New Public Management approach.

New Public Management (NPM) emerged in the United Kingdom during the Thatcher and Major governments in the 1980s and 1990s, subsequently adapted in many different ways around the world [32]. In general, it focuses on using approaches from the private sector in public management. The basic idea is that a government outsources a number of its tasks via competitive contracting, increasing the efficiency and the quality of the public service delivery and leading to an increased value for the taxpayers' money. It is considered that the private sector, motivated by market incentives, is better capable of efficiently delivering a number of public services, within the conditions set by government. The public administration itself should thus insist on accountability, supported by methods such as tools as performance-based budgeting. This then results in reducing governments in search of their most effective size and shape, accomplished through strategic reviews, consolidation, and reorganisation and leaving those tasks to the market to which the market is best equipped.

From a democratic point of view, NPM creates, in theory, more transparency and a better understanding of how the government spends public money. Central to NPM is, namely, the use of performance measurement systems that enhance the legitimacy and accountability of government operations. Consequently, based on these analyses, one should be able to detect if a government performance is 'good' or 'bad' based on predefined criteria. However, this is the case in theory. The challenge is to operationalize this. As explained by Moore [33], at first, the need for objective measures seems to be a technical one to measure the success—or not—of public organizations in altering 
social conditions in order to create public value. However, in turn, it becomes a managerial problem as to how to deploy such technical tools in combination with day-to-day activities in organizations; for example, how to hold someone accountable for their performance? At that point, it exposes a political problem: what is the value that is pursued?

\subsection{The Lack of Strategic Management can Constrain Sustainable Development}

The main limitation of NPM is the difficulty, or even impossibility, to attribute observed changes in social conditions. Causality is difficult to observe due to the many intervening variables. In addition, in many cases, changes need a long time before they visibly emerge. The feedback comes in late, which makes it little verifiable to relate change to the daily operations and adjust and improve them if needed. Consequently, the NPM focus on measuring results to improve the accountability led not to a predicted 'creative destruction' [34] of inefficient and ineffective public services, but to a defensive behaviour of public agencies and to an endless discussion on the definition of public value. With, amongst others, its ill-defined character and absence of agreed-upon evaluation criteria, the NPM concept qualifies as a 'wicked problem' [35]. The result of this all was that, rather than focusing on solving societal problems, public agencies started to focus on justifying past performance, leading to stronger institutional inertia instead of change. Such reinforcing feedback mechanisms leading to institutional lock-in and reduced or absence of organisational responsibility for collectively produced outcomes have also been observed by Ulrich Beck in his work on the 'risk society' [36].

Following this, one crucial element of private agencies' behaviour did not immediately find its way to public governance, namely, strategic management [33]. Strategic management has been developed in the business world to guide the often-by-scenarios driven decision-making of private-sector firms [37]. Nonetheless, strategic management was incorporated in public management, albeit in a slightly different way [38]. Strategic management in public governance does not focus on the uncertain risks. In contrary to private policy-making, it focuses on a desired future, giving attention to the aspects that are controllable and less the external complex and dynamic environment that influences development [33,39].

Especially for sustainable development, taking into account the external complex and dynamic environment, when aiming to achieve a desired future, is important. Sustainable development-thus also the CE as its 'newest' concept-requires strong strategic management, combining the private- and public-sector understanding of this instrument. Contributing to changes in the long term requires the alignment of different stakes in the short term and the long term. However, as explained by Boons and Spekkink [40], in many countries, the responsibility for sustainable development, in light of NPM, has since the 1980s been externalised for a large part to the private sector. Hereby, the role of the government has evolved to the facilitator of transformation, setting the long-term goals, while market mechanisms were expected to incentivize private parties in making the changes needed to achieve the goals. The private-sector and market-dominated process poses a challenge for the strategic management of sustainable development for public governments, as they are not (anymore) directly in control of the effective (re)production capacities.

\section{Operational Framework}

To guide public managers in a complex and dynamic environment, Moore [31] introduced his strategic triangle. The strategic triangle informs public managers as to how to create public value by successfully aligning the sources of legitimacy and support of the public value and the operational capacity. Within the triangle lies then the strategic management, or the area of control of the decision-makers (Figure 1). 


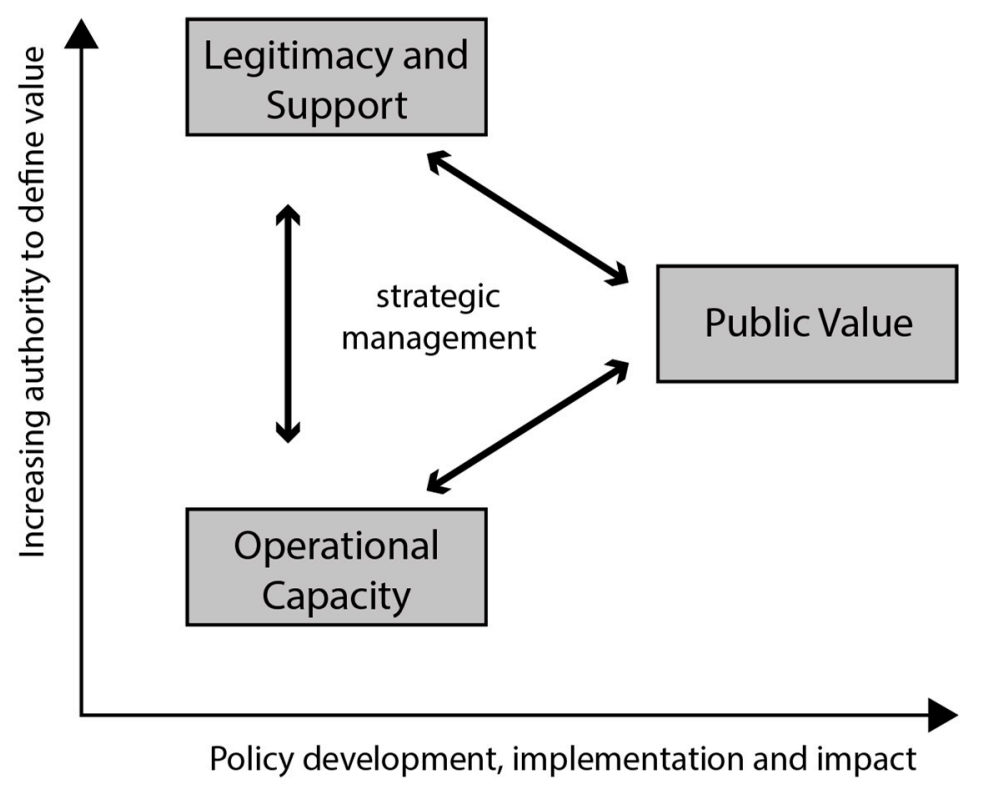

Figure 1. The Strategic Triangle (Moore [31])

In this paper, we regard the $\mathrm{CE}$ as a public value that, however, is 'still in the making.' While a lot of attention has already been given to describing the legitimacy and support of the $\mathrm{CE}$, especially during recent years (cf. [41]), arguably less attention has been given to the operational capacity to enhance a CE. Moore [31] defines the operational capacity as the developed capacity to achieve the desired result. Translated to the CE, we understand the operational capacity thus as the capacity within a given location, in this case Ghent (Flanders) and Amsterdam (The Netherlands), that can enable activities to become (more) circular. While these activities can be also software or orgware, in this paper we focus on the hardware operational capacity, understood as the technical capacity to make existing production and consumption processes more circular. Moore's triangle thus enables us to link the political and public administrative side of the $C E$ with the operational capacity, which is an economic and technical view on the CE. In other words, the triangle checks if the policy ambitions are in line with the existing economic operational capacity. If the legitimacy and operational capacity is aligned, according to Moore [31], a public value can emerge. However, methodologically, it is arguably impossible to assess the operational capacity of the CE. Every product has different parts, which have, again, different applications and require different (re)production processes. In addition, in geography and time, these differ significantly. Therefore, we take into account the non-, or negative-operational capacity of the CE, based on the ladder of Lansink (Figure 2).

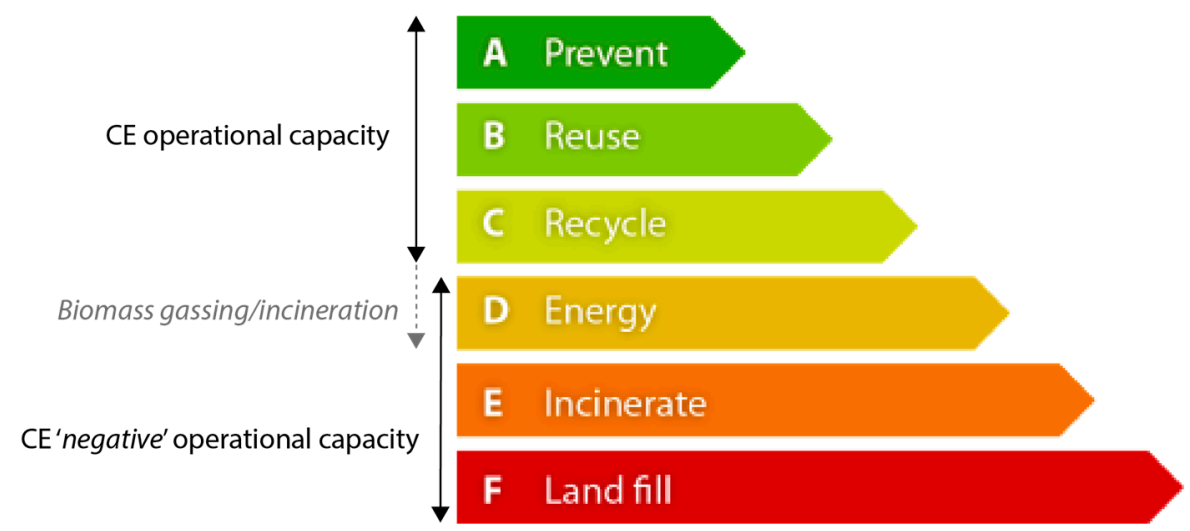

Figure 2. The ladder of Lansink and the (negative) operational capacity of the circular economy (CE) (source: authors). 
Different from the 'positive' CE operational capacity, the 'negative' operational capacity is the same for all products and materials: all materials or waste that are sent to a landfill or are being incinerated cannot be recycled or reused. Otherwise stated, landfills and incinerators can be seen as the CE's negative operational capacity, arguably thus producing a negative circular public value. Note that many incinerators also generate ('green') energy, given that waste-to-energy solutions have been considered to deliver 'green' energy according to the European directives on renewable energy and on biomass [42]. We, however, take incinerators into account that burn all kinds of waste, or residual waste, including biomass. Biomass that is collected separately, is being exclusively gassed and/or incinerated to generate energy, is here not included and can be regarded as a 'grey zone' for sustainable development (Figure 2). Nonetheless, we are aware of the contested status given the many perverse incentives that possibly annihilate the reduction of the environmental impact; for example, by growing forests for incineration or by importing bio-waste, thus generating transport-related emissions and impact [43].

To assess the current public value of $\mathrm{CE}$, we will map the (un)alignment between the CE public management legitimacy and support, and the economic and technical CE negative operational capacity. We focus hereby on the port cities of Ghent and Amsterdam, respectively in Flanders (Belgium) and The Netherlands. We have chosen these two port cities because, first, both Flanders and The Netherlands are seen as forerunners in waste management within Europe [44,45]. Second, while both the cities of Ghent and Amsterdam have stated clear circular policy ambitions for their urban economies, also their ports-and thus their port authorities-have put the CE as a central policy ambition for their maritime economies. Third, arguably, port cities are administrative regions or municipalities wherein both (re)consumption and (re)production can (potentially) be organised. Internationally, in general, two main categories of waste are distinguished: household waste and company waste. Within port cities, these two categories are present in significant amounts. Fourth, in regard to a full CE, port cities can potentially become places were thus (re)consumption and (re)production is better aligned, an argument that is today already used within the discourse of the port of Amsterdam to safeguard its license to operate [22]. Summarized, port cities can offer a lens on the challenges between the alignment of $C E$ policy ambitions and the CE operational capacity to facilitate this. We base our analysis on a historical analysis of the waste management in Flanders and The Netherlands, eventually assessing Moore's triangle today.

\section{Results}

\subsection{The EU Waste Reduction Policies}

The European Commission (EC) has a long tradition on regulating waste and supporting recycling activities. For municipal waste (MSW) the important directives are the Packaging and Packaging Waste Directive (94/62/EC) [46], the Landfill Directive (1999/31/EC) [47], the Directive on the incineration of waste (2000/76/EC) [48], and the Waste Framework Directive (WFD, 2008/98/EC) [49]. The latter sets the bar of minimum $50 \%$ recycling, increased to $60 \%$ by 2025 and $65 \%$ by 2030 , in its 2015 report [10]. Nonetheless, discrepancies in their implementation and the Union's aspiration to become more circular by the middle of this century, made an amendment of WFD needed. Perhaps, one of the main reasons for a Directive change was the Waste-to-Energy debate on its role in the CE. While the WFD resorts on Lansink's ladder, some authors and organizations (e.g., Zero Waste Europe, Global Alliance for Incinerator Alternatives) believed that much more attention was put on incineration than on waste prevention and recycling [50]. Proof of this is that the EC highlights the opportunities for energy recovery through incineration in its Science Hub, through an article by Scarlat et al. [51] setting the potential for almost 250 new incineration and co-firing plants in Europe. Directive 2018/851/EC [52] came to amend the WFD with the aim of transforming current European's waste management into sustainable material management, providing a definition of material recovery apart from energy recovery, and, among other measures, seeks to avoid support to landfilling and incineration among local and regional authorities. Likewise, the European Green Deal [53] privileges the opportunity to 
expand sustainable and job-intense economic activities, sustainable product policies with the potential of significant waste reduction, and the stimulation of a potential lead market by developing new technologies and sustainable innovative solutions to waste.

\subsection{Flanders-Ghent}

The institutional waste landscape in Belgium is regionalized (cf. Flanders, Brussels, and Wallonia). First, for household waste, every region is responsible for the waste plans, while—as in most European countries-municipalities are responsible for the collection and treatment. During the second half of the 20th century, municipalities increasingly experienced difficulties to cope with the growing amount of waste [54]. There were several reasons for this. First, the increased use of artificial fertilizers in the agriculture sector turned human, animal, and organic waste useless. Second, increasingly gas and gasoline were used to centrally heat buildings, making families let go of their 'individual' waste-to-energy: their fireplaces. Third, the increasing consumption society resulted in an increase of plastics and packaging materials that not only increased the amount of waste, but also became mixed with other (re)usable waste, thus making it all unusable. This resulted eventually on its top during the 1970s, in around $250 \mathrm{~kg}$ residual, or unusable, waste per capita per year-in total 1.5 million tonnes-that was generated in Flanders [54]. At that time, there was almost no treatment opportunity for this residual waste. The standard procedure was to dump the waste into large landfills or to (non-filtered) incinerate it, only sporadic with waste-to-energy. From the beginning of the 1970s, the Belgian state increasingly started to subsidise incinerators. An important reason was the oil crisis, which made waste-to-energy more lucrative [54]. Incinerators remained, however, more expensive than landfills. Within Flanders/Belgium, numerous landfills existed and, although there were protests [54], they remained an important destination for national and international waste. Illustrative is that, in 1979, the municipality of Amsterdam intended to dump 400,000 tonnes of household residual waste in the municipality of Rupel [54], which was eventually cancelled [54]. Eventually, in 1983, it was forbidden to use the Flemish landfills for non-Flemish waste. However, since waste is regionalized in Belgium, for years, Dutch residual waste was landfilled in Wallonia [54,55].

From the mid-1970s, the first separate waste collections were organised. Following the European directive on waste [56], also Belgium, and thus Flanders, had to come up with a waste plan. Because of the political restructuring of Belgium, the Flemish decree on Waste Products eventually came into force in 1985 [57] and became renewed every five years [54]. This first plan focused on regulating, closing, and cleaning the existing numerous landfills (in 1983 there were 455 landfills, of which only one-third had a permission, [54]) to optimize the use of incinerators and to increase the separate collection of waste. During the 1980s, the total of household waste, from which first $31 \%$ was combusted and $44 \%$ went to a landfill, changed to $55 \%$ and $20 \%$, respectively [54].

In 2018, on average $468.5 \mathrm{~kg}$ per person per year was collected in Flanders. Of this household waste, $68.9 \%$ (up from $10 \%$ in 1988, [54]) was recycled (44.2\%) or composted (21.5\%). This resulted in $145.6 \mathrm{~kg}$ per person per year as residual waste [58]. Of this residual waste, after, for example, sand is separated, $91.3 \%$ is incinerated with energy recuperation ( $30 \%$ of the total amount of waste). Among the residual waste, more than half $(56 \%)$ is still recyclable or compostable [58]. Hence, to further encourage the municipalities to increase the prevention and the separate collection of waste, the Flemish Public Department of Waste (OVAM) has set the bar on average in Flanders to $138 \mathrm{~kg}$ per person per year in 2022 [59].

Next to household waste, there is company waste. For a long time, company waste did not receive any attention as the economy prevailed over ecology. However, during the 1970s, especially the treatment of the enormous quantities of often-dangerous industrial waste became an important political debate in Flanders. Until then, in most cases, industrial waste was being dumped on land or in the sea or being incinerated on land or via large incinerator ships. If this was not possible, industrial waste was exported. However, the European Union started to forbid dangerous waste being 
transported across borders (finalized in [60]). Similarly to household waste, company waste treatment became a mandatory aspect, and to date, it is being separated into reusable and residual waste.

In Flanders, the total household waste in 2018 was 3,087,209 tonnes (Figure 3). Of this, 959,204 t were household residual waste (around $70 \%$ is thus at least recycled). After another legal specification of waste handling, for example, the exclusion of sand and other non-flammable elements, $91.3 \%$, or around 876,000 tonnes went to an incinerator [58]. Annually, around 8 million tonnes of company waste are generated (2016: 8.2 Mtonnes) [61]. Around $85 \%$ is reused, thus higher than for household waste, while around $15 \%$ is incinerated or landfilled ( 881,036 tonnes). While the household residual waste had decreased from 1,016,604 tonnes in comparison with 2013, company residual waste saw an increase of $5.8 \%$. Even corrected with the increased employment, relatively, company residual waste increased, implementing that it has to decrease by $15 \%$ towards the 2022 goal. OVAM [58] did an analysis on the company residual waste and found that around $44 \%$ of the waste could be reused.

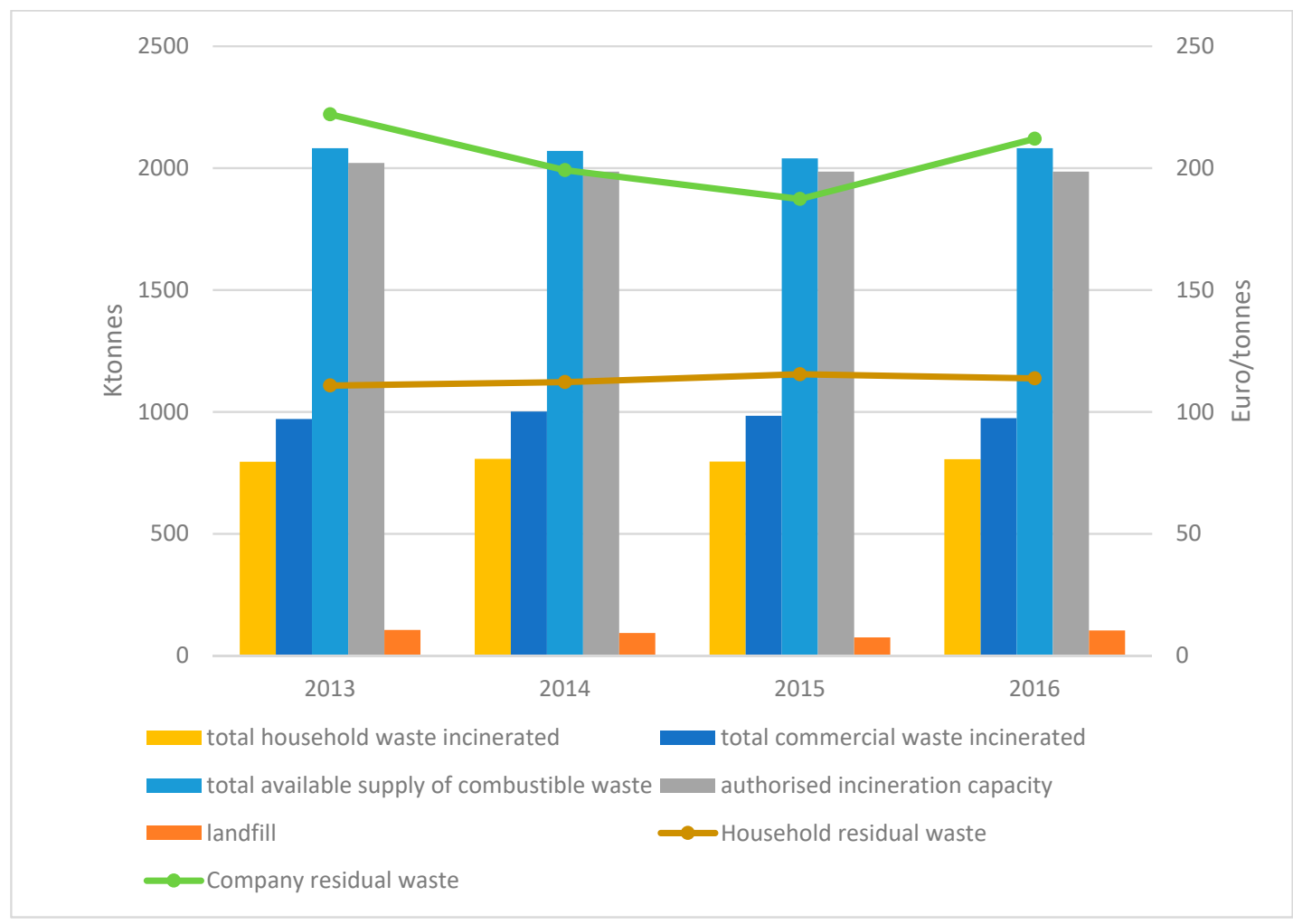

Figure 3. The total and deviation of amount of incinerated waste and landfill in Flanders, and the evolution of the prices for incineration in Flanders (figure: authors). Note that these prices are a combination of taxes (around 10\%) and operational costs. For company residual waste, the prices are a combination of the two prices for low and high calorific waste [62].

In total, taking also into account other smaller residues, there was a total supply of almost 2 million tonnes $(1,978,224$ tonnes) of waste that could be incinerated in 2018. This is higher than the available incinerator capacity in Flanders, which is $1,867,754$ tonnes. In other words, within Flanders, in 2018, there was a shortage of around 80,000 tonnes incinerator capacity [62]. This deficit is being exported or (temporally) sent to a landfill (Figure 3). In 2020, an extra 100,000 tonnes capacity will be opened, which, in other words, will imply that the total supply of household and company waste is approximately the same as the capacity of incinerators in Flanders. OVAM, via the Flemish Government, actively controls the total capacity of incinerators in Flanders [59]. The basic idea here is to encourage separating and reusing waste, and only in a last stepping to combust it [54]. By capping, and gradually lowering, the incinerator capacity in Flanders, the prices for incineration are deliberately kept relatively high (Figure 3), to thus encourage higher steps on the ladder of Lansink. 
Ghent is a port city located in the west of Flanders. The city hosts around 250,000 inhabitants. In 2018, the port of Ghent merged with the Dutch port of Zeeland, creating the European North Sea Port (NSP) port authority. Both the city as well as the port authority have stated their circular ambitions [63-65]. First, the city of Ghent has put the CE as an inclusive resilient future of its urban economy that is able to lead the transition of its employment structure. Under this umbrella, it has put six themes to the forefront: mobility/logistics, circular building, water, materials, food, and local production. In general, the city of Ghent plans to achieve a CE whereby materials are reused as much as possible, combining a network view (of actors and materials) with a geographical view (to keep it as local as possible) [65]. Moreover, Ghent explicitly states that it wants to become a 'glocal' production place, whereby as much as possible is produced locally, with global import and export where needed [64]. Ghent operates its own incinerator where it combusts the residual waste of its inhabitants. The incinerator has a capacity of 100,000 tonnes per year that generates heat and electricity for its own purposes as well as for a nearby hospital. The capacity is sufficient to process the residual waste of Ghent and several neighbouring municipalities [54].

Second, the North Sea Port has an overall sustainable strategy to strive for climate neutrality of 50\% in 2030 and 100\% in 2050 [63]. To achieve this, it prioritizes four strategies: (i) sustainable energy production, (ii) the use of hydrogen, (iii) circular production, and (iv) the storage and use of $\mathrm{CO}_{2}$. In practice, on the one hand, the NSP is a partner, with the city of Ghent among others, of the Cleantech Cluster Ghent, wherein via subsidies and projects circular practices are subsidised. On the other hand, the NSP will further extend its Flemish/Dutch pipeline infrastructure within its port area and towards the hinterland, whereby both materials as energetic products (e.g., $\mathrm{CO}_{2}, \mathrm{H}_{2}$ ) can be exchanged [66].

\subsection{The Netherlands/Amsterdam}

During the 20th century, similar to Belgium and many other countries, waste treatment was the responsibility of local municipalities. The dominant processing of waste was via landfills. However, following the increased economic activity, the amount of waste grew and also the contamination of it by synthetic products [67]. During the 1970s, the ecological cost and the impact on our planet became higher on the agenda, notably by the Club of Rome [68]. Within the European Union, The Netherlands, arguably, took a leading role in the regulation of the waste sector. Illustrative is that parliament member Ad Lansink became linked to the then-introduced 'ladder of Lansink' (Figure 2), which is yet much referred to as a leading principle for sustainable development [55]. Therefore, this is different from Belgium. The Netherlands, some ten years earlier, in 1979, introduced laws regulating chemical and regular waste. Consequently, it became very difficult to keep on using landfills. As these laws did forbid the import of waste-the opposite of today-they did not forbid the export of waste. Thus, since the landfills in Flanders were not yet strictly regulated, soon a significant flow of residual waste was transported from The Netherlands to Flanders and, after 1983 until the 1990s, to Wallonia [54,67].

During the 1980s and the beginning of the 1990s, a significant restructuring took place of the Dutch waste infrastructure. The main concern was to better organize the waste processing capacity of Dutch waste, instead of exporting it to other countries (e.g., Belgium). Therefore, a significant increase of public investments in incinerators took place, and the responsibility became centralised to the national level.

In 2018, 8.5 million tonnes of household waste were collected. This results in $494 \mathrm{~kg}$ per inhabitant per year, a decrease of around $60 \mathrm{~kg}$ since 2008; $206 \mathrm{~kg}$ consisted of residual waste (34.8\%), $288 \mathrm{~kg}$ were collected separately $(65.2 \%)$. Absolutely and relatively, these figures per capita are comparable with Flanders. In total, around 3 million tonnes of household waste annually were combusted [69]. Next, around 4.5 million tonnes of company residual waste were combusted in 2018 [70]. Different from Flanders, no combustible residual waste was sent to landfills (Figure 4). 


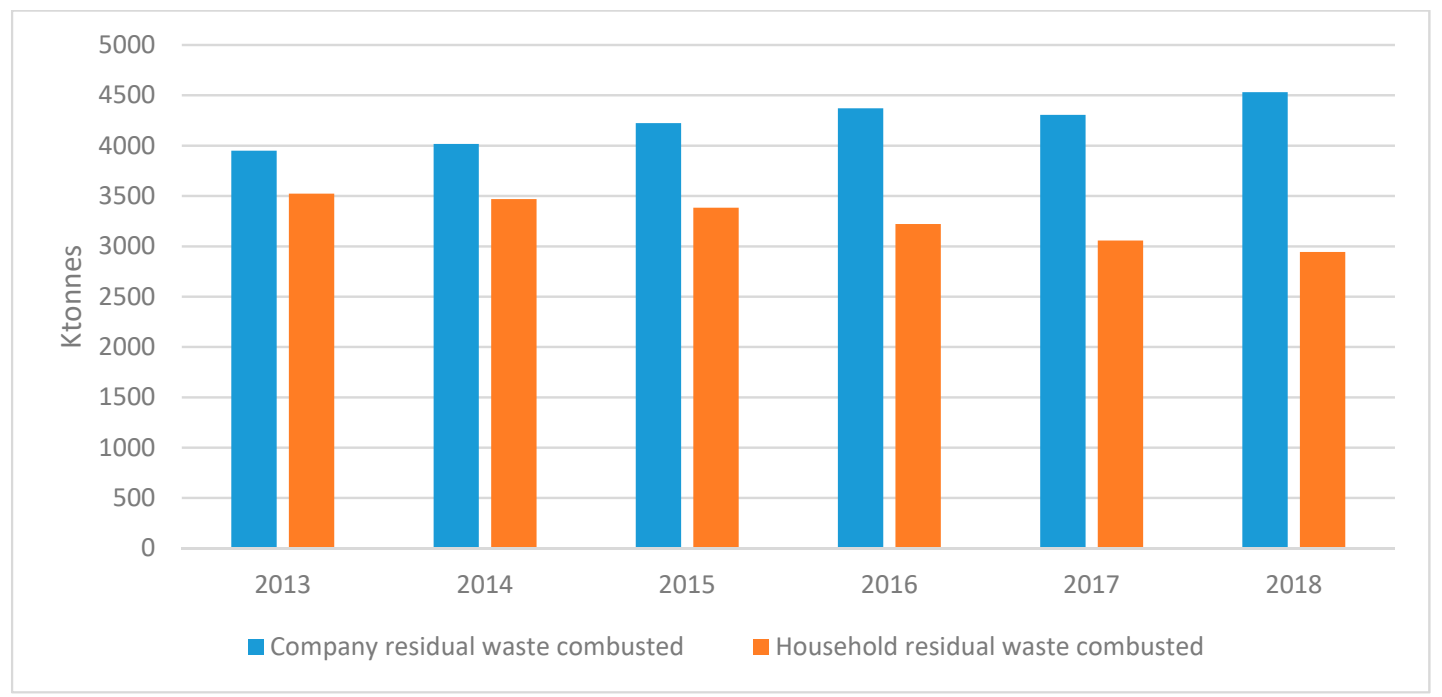

Figure 4. The amount of company and household residual waste combusted and the total landfill (figure: authors, data from [70]).

The reason for this is because the incinerator capacity in The Netherlands is significantly higher than the supply of combustible waste. While in 1980 the incinerator capacity was 2.2 million tonnes, this increased to almost 8 million tonnes today [55]. (Figure 5). The increase of incinerator capacity was needed to prevent the growing amount of waste from being landfilled. Especially by the end of the 1990s, new incinerator technologies were introduced to further reduce the emissions through placing filters and optimising the energy recovery of the plants. In addition, the Dutch Government encouraged the use of the residuals to make concrete, especially for road and infrastructure constructions. From the 1980s to the beginning of the 21st century, the incinerator capacity doubled [67].

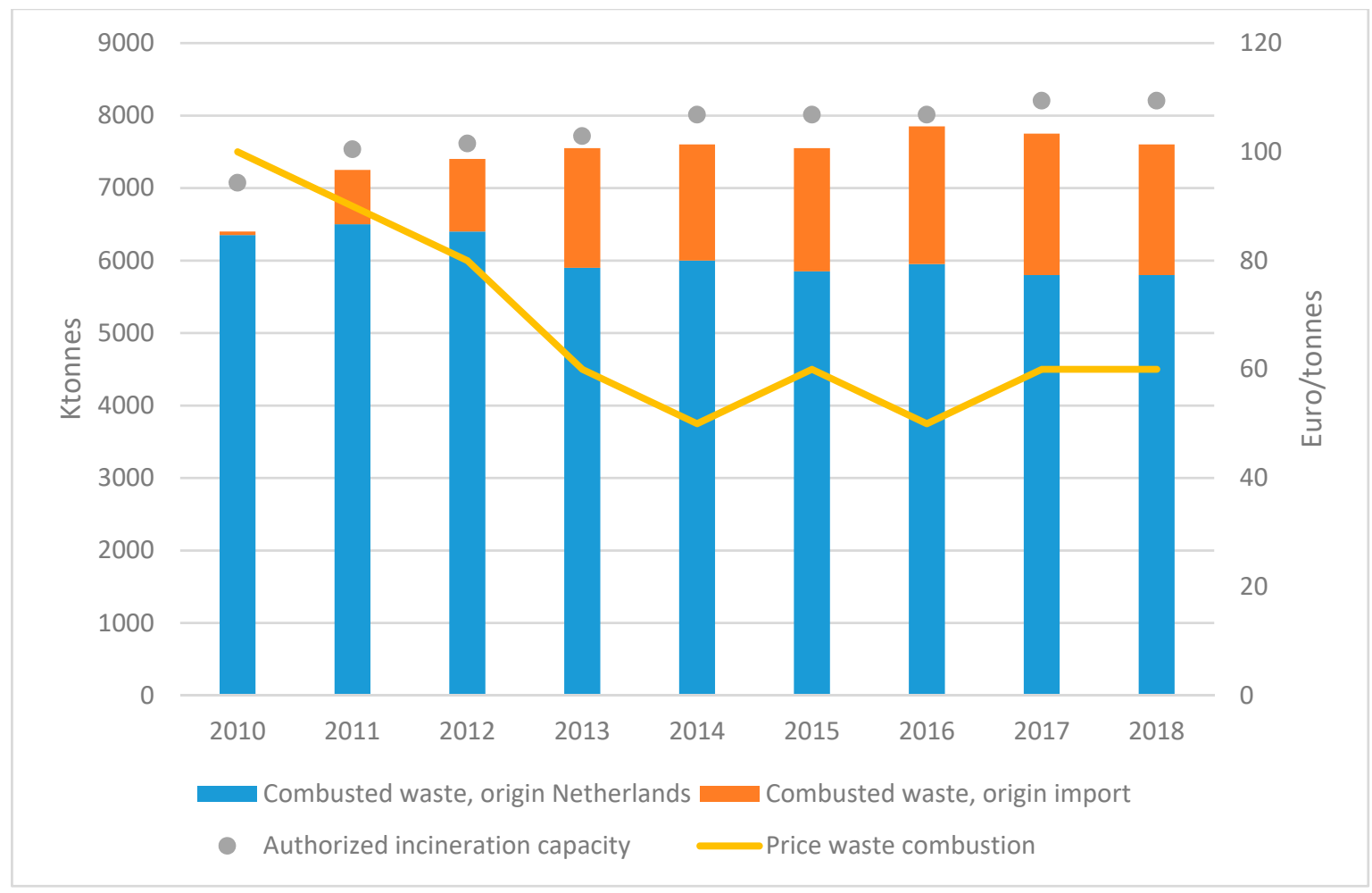

Figure 5. The amount and origin of combusted waste, the authorized incineration capacity in The Netherlands, and the evolution of the price of combustion (figure: authors, data from [70]). 
From the beginning of the 21st century, an important shift occurred in the Dutch waste policy [55]. Waste became regarded as a valuable economic good. While this was derived in the first place from an ecological point of view, a consequence was also that the waste became an economic market and, as all other economic markets, should have its own (inter)national regulations and privatized companies. This led to the fact that, in 2006, it was allowed that non-Dutch waste could be imported, while until now, exporting waste is still taxed highly. Thus, the waste management of The Netherlands became linked with the waste management of other countries. As explained by [67], the situation in the 2000s was that The Netherlands had chosen incinerators and re-use as the main options; Belgium focused on consumers and recycling, and the United Kingdom for landfilling.

During the last decade, a lot has changed. First, in The Netherlands, the amount of combustible waste kept on decreasing and is supposed to decrease towards 5 million tonnes in 2022. At the same time, the incinerator capacity kept on growing. This led to two intertwined effects. First, an overcapacity of incinerators illustrated that, since 2010, 1 million tonnes capacity has been added. Since incinerator plants need a minimal operational flow of waste, foremost waste from the United Kingdom is today imported to The Netherlands, around 1.5 million tonnes today. Remarkable is that, during the beginning of the 2010s, within policy reports this was perceived environmentally positively [71]. This was based on the difference of environmental effects of or sending waste to landfills in the United Kingdom or transporting this waste to The Netherlands towards its incinerators; the latter thus being more environmental positive than the former. Without going further into that in this paper, this changing point of view is a consequence of taking into account or not the effect of 'problem displacement' [25], or here, arguably, the opposite 'problem inclusion.' While with problem displacement there is a lack of responsibility to tackle the (environmental) problem, here one is dependent on the lack of responsibility of another actor. Second, the price of incineration decreased significantly, from around 100 euros per tonne in 2010 to around 65 euros per tonne today (Figure 5). This is significantly lower than in Flanders.

Arguably, within The Netherlands, the port and city of Amsterdam are leading in terms of CE ambitions. Already in 2015, the city of Amsterdam launched its circular plan, which has been renewed in 2020 [72,73]. The city has appointed three focus areas: food and organic flows, consumption goods, and the built environment. These are three of the five focus areas appointed by the Dutch Government [12]. Of these five, the industrial sector and plastics are not appointed as a priority for the city of Amsterdam [72]. The port authority of Amsterdam has put the CE as part of its central strategy since 2016 [74]. Since then, CE has only become more important for the port authority within its strategy, albeit this is part of its strategy to defend its license to operate following the particular situation with the city of Amsterdam regarding a land use conflict between maritime and urban land use $[75,76]$. Remarkably, this land use conflict is using on both sides the CE discourse, albeit different 'parts' of the CE are chosen [22]. The city authority, aiming to redevelop an existing maritime area close to the city into a new residential area, uses circularity within its plans linked to the built environment. Their reasoning is that the new built area will be constructed in a circular way (e.g., design, material use) that will help to achieve its $\mathrm{CE}$ ambitions. The port authority, though, uses circularity understood in (re)production processes. They claim that the area under discussion is needed to host circular functions (e.g., waste treatment) that are located as close as possible to the city; this to avoid thus the effect of 'problem displacement' [25,26].

\section{Discussion}

Using this triangle as a framework, we can now bring our results together (Figure 6). Our results show that, arguably, Flanders and The Netherlands in terms of waste management have switched positions recently. The Netherlands, with their early national waste management plans, were during the 1970s and 1980s a forerunner in terms of sustainable development. Illustrative for this is that their national ladder of Lansink became also an internationally known strategic and policy tool for short- and long-term environmental policy [27]. While at that time the incinerator capacity 
in The Netherlands was not sufficient, significant flows of waste were sent to landfills in Flanders and later to Belgium. This shows that, in Flanders, ecology was not high on the policy agenda, and the (linear) economy prevailed.

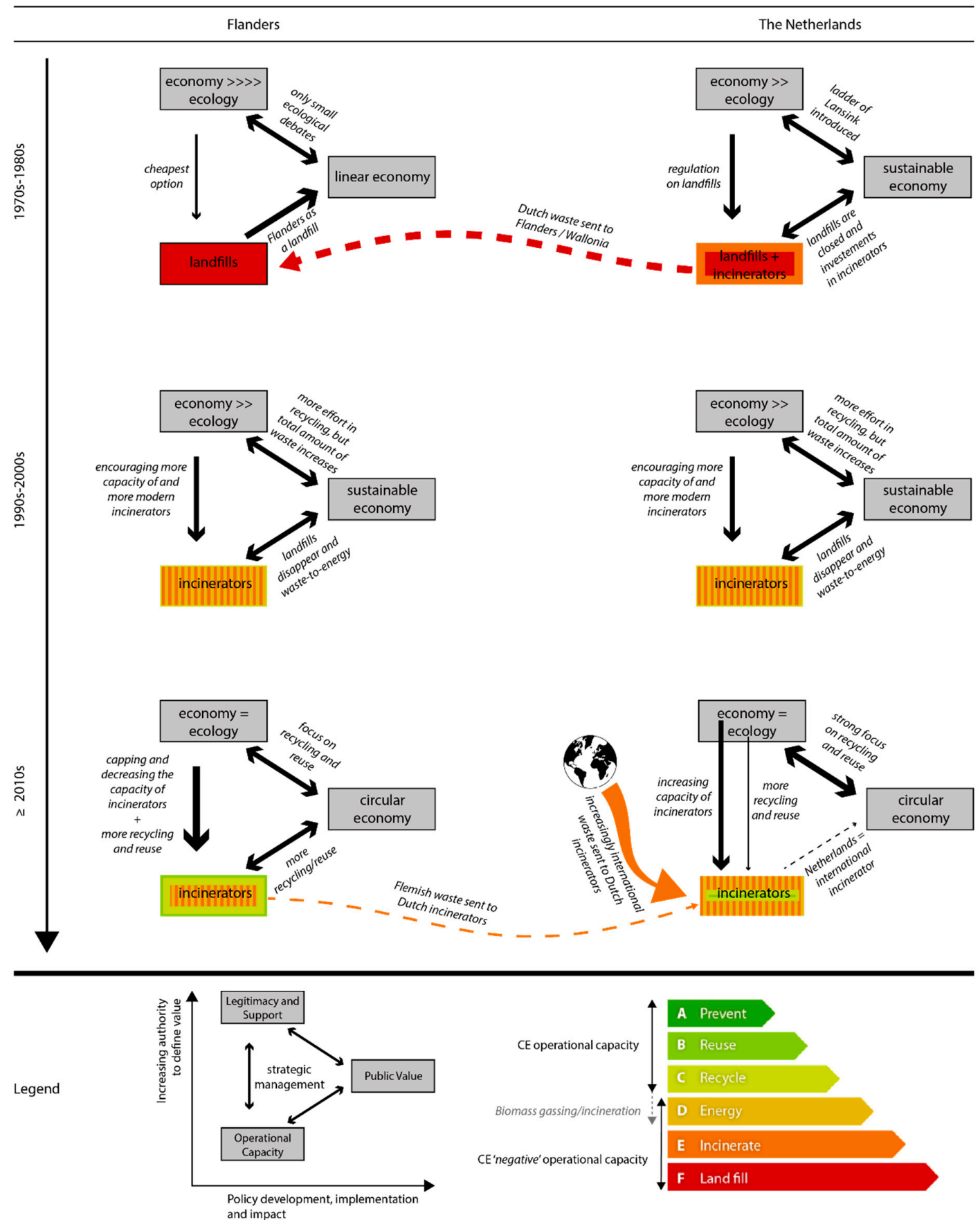

Figure 6. The result of the mapping of the evolution of waste management in Flanders and The Netherlands, using the triangle of Moore and the ladder of Lansink (1995) (source: authors).

During the 1990s, Flanders gradually caught up with The Netherlands. Incinerators were built and modernised, and, at the same time, attention was given to recycling and reuse. Nonetheless, the amount of waste kept on growing, both in Flanders and in The Netherlands, following the increased economic activity and the growth of population. However, landfills gradually were closed, 
and, in both Flanders and The Netherlands, relatively more waste was recycled, with incineration and, finally, landfill as last resorts.

The Legacy of an Internationally Oriented New Public Management Hinders a Balanced Local-Oriented CE Triangle

This brings us to the centre of the triangle of Moore [31]: strategic management. As explained, to successfully create a public value, one needs to align the legitimacy and support with the operational capacity-hence the strategic management. In light of creating the $C E$ as a public value, two essential aspects are needed: (i) the recycling, reuse, or refuse of materials, and (ii) striving to do these as local as possible. The first aspect is used to foster innovation and increased employment $[15,34]$ in the existing activities or to attract non-existing activities and employment in that particular region. The second is used to link this to the spatial planning of such innovative CE. Both aspects explain to some level—next to for example climate change goals—why many local administrative governments, like port cities, put the CE as a central policy ambition for their economies. This will demand, especially in The Netherlands, a difficult transition. With the dawn of the 21st century, The Netherlands had optimized their waste management. At this moment, an arguably lock-in emerged that focussed on waste incineration. We understand lock-in here as the situation whereby two systems, in this case waste management and waste treatment, are so much linked to each other that the situation in one of the systems hinders, or locks, the other one from evolving. This lock-in between the ladder of Lansink and the incinerator capacity explains why the strategic management towards a CE of the port city of Amsterdam is more limited than the one of the port city of Ghent. The lock-in of Amsterdam can be linked to two main reasons. First, increasingly the European environmental ambitions were heightened. In particular, the European Commission raised its ambitions on renewable energy sources (RES) for electricity (RES-E) and transport (RES-T). According to Hoppe and van Bueren [77], Dutch shares of RES were disappointing compared to the Union's ambitions, for the Dutch electricity system is "best described as a fossil-based thermal system, dominated by inexpensive natural gas and coal as main production sources" (p. 67). Likewise, the modest target of $9 \%$ by 2010 and $17 \%$ in 2020 of the Directive 2001/77/EC [78] on RES-E was not seen as a threat, since RES-E was produced from biomass and different types of waste were considered as such. The latter brings us to the second main reason. From the beginning of the 2000s, The Netherlands-in line with NPM-began to see waste as an economic good and incinerators as assets that could be financially break-even and rely on forms of self-regulation within the regulatory framework set by central and local governments. This created an internationally oriented incinerator market in The Netherlands. In other words, the NPM principles here got mixed with the sustainable goals of waste-to-energy as an ideal win-win solution: manage waste, while increasing the share of 'green' energy, as demanded by the EU.

This is in contrast to Flanders, where the capping of the maximum allowed amount of incinerator capacity was deliberately kept low, and from 2022 even will decrease. The prices to incinerate are therefore significantly higher in Flanders than in The Netherlands, especially during the last decade. The lock-in in The Netherlands has even increased, as more and more waste-to-energy incinerators have been connected to heat networks, also to decrease the use of natural gas. Consequently, there is an increasing demand of this type of generated heat, thus an increased need to combust waste. This makes the (local) energy system dependent on waste combustion. More recently, this became a greater challenge, because, as in the rest of Europe, increasingly the CE is embraced, and thus the prevention of waste is strived for. Already in the figures, it can be seen that the total amount of residual waste is decreasing. Therefore, not only because of the increased capacity of incinerators, but also of the increased link with local heating networks, The Netherlands has to import waste.

To summarize, if one wants to assist the (potential of) local CE strategic management, one should analyse how the triangle is (un)aligned (Figure 7). Only in this way, the potential of a CE within a port city, and thus the (re)connection of port and city, could be achieved. Essential for a $\mathrm{CE}$ is that materials 
are at least recycled, but also remain as local as possible. Such localization requires not only dedicated and consistent regulative frameworks across scales and sectors, but also an operational capacity that is not (only) aimed at optimizing economic drivers, but also takes into account the ecological aspects of these.

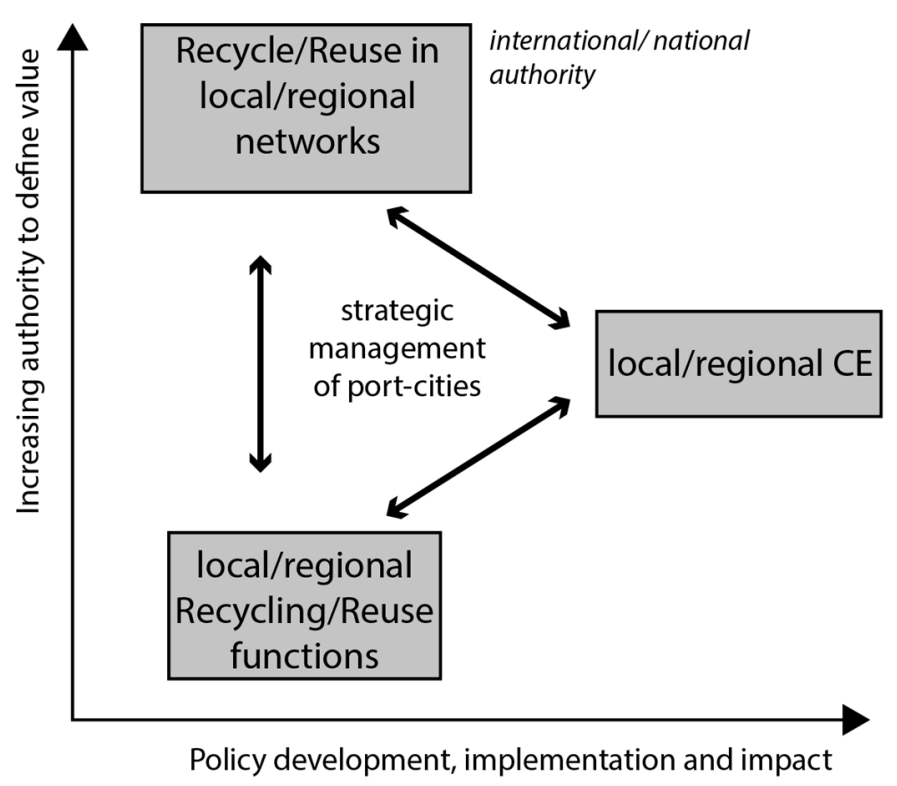

Figure 7. The strategic management of port cities to create a local/regional CE.

\section{Conclusions}

This paper focussed on the potential of the CE strategic management of local port cities, by not focusing on them in the first place. Local authorities, in cases such as the port cities of Ghent and Amsterdam, have increasingly put forward the $\mathrm{CE}$ as their core future socioeconomic business model. Similar to other concepts in the past, increasingly, policy documents and ambitions are formulated in this field. Arguably, Amsterdam is seen as an (international) forerunner, both the urban government as the port authority, following their clearly stated ambitions and regulations (cf. [79]). As explained by Moore [31], it is, however, also necessary that these policy ambitions are aligned with the operational capacity to enable the emergence of the CE as (local) public value. In other words, urban regions which have the space for and/or already host industrial (re)production or logistical functions, have a higher potential to adapt to a CE compared to urban regions which, to date, do not have the space and/or industrial (re)production or logistical functions.

Our results show that, in this respect, the CE policy ambitions of Ghent are more realistic than those of Amsterdam. In The Netherlands, in light of NPM, the waste management sector has developed towards an internationally oriented incinerator sector, competing on market prices. During the last decade, the capacity of incinerators has increased, while the price has decreased significantly. In addition, increasingly the incinerators have been linked to waste-to-energy heat networks, creating all together a lock-in between waste management and waste treatment, resulting in that the ladder of Lansink 'is stuck on' the incinerator step.

Bringing this back to Amsterdam, in reality, it is increasingly relatively more expensive to recycle, reuse, or refuse materials, than to incinerate waste. Thus, if at least circular programs are not subsidised or increasingly other factors (e.g., social and/or environmental externalities) are taken into account within the price, the circular business models of Amsterdam-based companies and organisations - and thus also the overall circular ambition of the port city of Amsterdam-, are less realistic compared to Ghent's. In Flanders, the incinerator capacity is capped and decreasing, keeping the incinerator price high to make recycling, reusing, or refusing more interesting over incineration. 
This will only become more if social and/or environmental externalities (e.g., $\mathrm{CO}_{2}$ ) are taken into account. If the legal framework and support are further improved (e.g., making it fiscally more interesting to reuse materials, create 'circular labels'), the operational capacity to enhance the $\mathrm{CE}$ (e.g., clusters) is more likely to happen.

Such context holds important policy recommendations for port cities and other governmental organisations. Creating a CE is not only about posing ambitious circular goals or to put all efforts in a successful story that lends itself ideally for marketing. The real challenge is to align the existing circular operational framework with these ambitions, fostering changes in the systems of production and consumption at operational levels rather than changes over the whole system, or transitions usually urged for. Especially for ports and their port authorities, that host international companies thriving on global production and supply chains, it is a challenge to help transit their business case towards locally recycling, reusing, or refusing of materials as much as possible. While much attention now goes to the 'positive' circular operational capacity such as establishing pipelines or altered (re)production processes, another way is to decrease the 'negative' circular operational capacity such as landfills and incinerators and thus decrease the 'negative' circular public value. If this is done, the incentive to, first, move up on the ladder of Lansink and, second, to remain as local as possible, will become bigger, therefore the potential of the policy ambition to let the CE emerge as a local public value.

Author Contributions: K.V.d.B. is the main author of the article. He has set up the idea and structure of the paper and has done the empirical research and writing. F.B.A. helped with the European legislation, E.v.B. helped with the theoretical part. All authors have read and agreed to the published version of the manuscript.

Funding: This research was partly funded by the expertise centre Accelerating the Circular Economy in Zuid-Holland (ACCEZ) of the Dutch province of South-Holland (grant number PZH-2018-658193468).

Acknowledgments: Although this paper was written during Covid-19 isolation time, we want to thank colleagues and the online discussions that helped to improve this paper. We also want to thank four anonymous reviewers for their valuable comments.

Conflicts of Interest: The authors declare no conflict of interest and the funders had no role in the design of the study; in the collection, analyses, or interpretation of data; in the writing of the manuscript, or in the decision to publish the results.

\section{References}

1. Harrison, J. Seeing like a business: Rethinking the role of business in regional development, planning and governance. Territ. Politics Gov. 2020, 1-21. [CrossRef]

2. Agnew, J. The territorial trap: The geographical assumptions of international relations theory. Rev. Int. Politics Econ. 1994, 1, 53-80. [CrossRef]

3. Bauwens, T.; Hekkert, M.; Kirchherr, J. Circular futures: What will they look like? Ecol. Econ. 2020, 175, 106703. [CrossRef]

4. Geissdoerfer, M.; Savaget, P.; Bocken, N.M.; Hultink, E.J. The circular economy-A new sustainability paradigm? J. Clean. Prod. 2017, 143, 757-768. [CrossRef]

5. Ghisellini, P.; Cialani, C.; Ulgiati, S. A review on circular economy: The expected transition to a balanced interplay of environmental and economic systems. J. Clean. Prod. 2016, 114, 11-32. [CrossRef]

6. Su, B.; Heshmati, A.; Geng, Y.; Yu, X. A review of the circular economy in China: Moving from rhetoric to implementation. J. Clean. Prod. 2013, 42, 215-227. [CrossRef]

7. UN. Circular Economy: The New Normal? United Nations: New York, NY, USA, 2018.

8. OECD. Business Models for the Circular Economy. Opportunities and Challenges from a Policy Perspective; Organisation for Economic Co-operation and Development: Paris, France, 2019.

9. COM. A New Circular Economy Action Plan. For a Cleaner and More Competitive Europe; European Commission: Brussels, Belgium, 2020.

10. COM. Closing the Loop-An EU Action Plan for the Circular Economy; European Commission: Brussels, Belgium, 2015.

11. Vlaamse Overheid. Vlaanderen Circulair. Een Stuwende Kracht Naar een Circulaire Economie in Vlaanderen; Vlaamse Overheid: Brussels, Belgium, 2017. 
12. Dutch Government. Nederland Circulair in 2050; Dutch Government: The Hague, The Netherlands, 2016.

13. Hobson, K. Closing the loop or squaring the circle? Locating generative spaces for the circular economy. Prog. Hum. Geogr. 2015, 40, 88-104. [CrossRef]

14. Carlson, A.; Burtraw, D. Lessons from the Clean Air Act: Building Durability and Adaptability into US Climate and Energy Policy; Cambridge University Press: Cambridge, UK, 2019.

15. PBL. Outline of the Circular Economy; PBL Netherlands Environmental Assessment Agency: The Hague, The Netherlands, 2019.

16. Reike, D.; Vermeulen, W.J.; Witjes, S. The circular economy: New or Refurbished as CE 3.0?-Exploring controversies in the conceptualization of the circular economy through a focus on history and resource value retention options. Resour. Conserv. Recycl. 2018, 135, 246-264. [CrossRef]

17. Zink, T.; Geyer, R. Circular economy rebound. J. Ind. Ecol. 2017, 21, 593-602. [CrossRef]

18. De Wit, M.; Hoogzaad, J.; Von Daniels, C. The Circularity Gap Report 2020; Ruparo: Amsterdam, The Netherlands, 2020.

19. Sunley, P. Relational economic geography: A partial understanding or a new paradigm? Econ. Geogr. 2009, 84, 1-26. [CrossRef]

20. McCombs, M.E.; Shaw, D.L.; Weaver, D.H. New directions in agenda-setting theory and research. Mass Commun. Soc. 2014, 17, 781-802. [CrossRef]

21. Valenzuela, F.; Bohm, S. Against wasted politics: A critique of the circular economy. Ephemer. Theory Politics Organ. 2017, 17, 37.

22. Van den Berghe, K.; Vos, M. Circular area design or circular area functioning? A discourse-institutional analysis of circular area developments in Amsterdam and Utrecht, The Netherlands. Sustainability 2019, 11, 4875. [CrossRef]

23. Sayer, A. Method in Social Science: A Realist Approach; Routledge: London, UK, 2010.

24. Van den Berghe, K.; Jacobs, W.; Boelens, L. The relational geometry of the port-city interface: Case studies of Amsterdam, the Netherlands, and Ghent, Belgium. J. Transp. Geogr. 2018, 70, 55-63. [CrossRef]

25. Korhonen, J.; Nuur, C.; Feldmann, A.; Birkie, S.E. Circular economy as an essentially contested concept. J. Clean. Prod. 2018, 175, 544-552. [CrossRef]

26. North, P. Eco-localisation as a progressive response to peak oil and climate change-A sympathetic critique. Geoforum 2010, 41, 585-594. [CrossRef]

27. Van den Berghe, K.; Dabrowski, M.; Ersoy, A.; Wandl, A.; van Bueren, E. The circular economy as re-emerging industry and the importance of the role of space [working paper]. Delft Univ. Technol. 2020. [CrossRef]

28. Swyngedouw, E. Globalisation or 'glocalisation'? Networks, territories and rescaling. Hist. Econ. Soc. Bull. 2004, 17, 25-48. [CrossRef]

29. Burger, M.J.; Stavropoulos, S.; Ramkumar, S.; Dufourmont, J.; Van Oort, F. The heterogeneous skill-base of circular economy employment. Res. Policy 2019, 48, 248-261. [CrossRef]

30. Storper, M. The Regional World: Territorial Development in a Global Economy; Guilford Press: New York, NY, USA, 1997.

31. Moore, M. Creating Public Value: Strategic Management in Government; Harvard University Press: Cambridge, MA, USA, 1995.

32. Hendriks, F.; Tops, P. Local public management reforms in the Netherlands: Fads, fashions and winds of change. Public Adm. 2003, 81, 301-323. [CrossRef]

33. Moore, M.H. Recognizing Public Value; Harvard University Press: Cambridge, MA, USA, 2013.

34. Schumpeter, J.A. Capitalism, Socialism and Democracy; Routledge: New York, NY, USA, 2003.

35. Rittel, H.W.J.; Webber, M.M. Dilemmas in a general theory of planning. Policy Sci. 1973, 4, 155-169. [CrossRef]

36. Beck, U. Risk Society: Towards a New Modernity; SAGE Publications: London, UK, 1992.

37. Wade, W. Scenario Planning: A Field Guide to the Future; Wiley: Hoboken, NJ, USA, 2012.

38. Hoetjes, P.J. Mapping the Market: A Portfolio Approach for Informed Deliberation of Urban Development Strategies. Ph.D. Thesis, University of Amsterdam, Amsterdam, The Netherlands, 2010.

39. Amer, M.; Daim, T.U.; Jetter, A. A review of scenario planning. Futures 2013, 46, 23-40. [CrossRef]

40. Boons, F.; Spekkink, W. Verinnerlijking van milieuverantwoordelijkheid in de Nederlandse chemische industrie. Over de complexiteit van meervoudige processen; Wetenschappelijke Raad voor het Regeringsbeleid: The Hague, The Netherlands, 2015. 
41. Salomone, R.; Cecchin, A.; Deutz, P.; Raggi, A.; Cutaia, L. Industrial Symbiosis for the Circular Economy. Operational Experiences, Best Practices and Obstacles to a Collaborative Business Approach; Springer: Berlin/Heidelberg, Germany, 2020.

42. Hoppe, T.; Van Bueren, E.; Solorio, I.; Jörgens, H. From frontrunner to laggard: The Netherlands and Europeanization in the cases of RES-E and biofuel stimulation. In A Guide to EU Renewable Energy Policy. Comparing Europeanization and Domestic Policy Change in EU Member States; Solorio, I., Jörgens, H., Eds.; Edward Elgar Publishing: Cheltenham, UK, 2017.

43. Bentsen, N. Carbon debt and payback time-Lost in the forest? Renew. Sustain. Energy Rev. 2017, 73, 1211-1217. [CrossRef]

44. EEA. Resource Efficiency and Circular Economy in Europe-Even More from Less. An Overview of Policies, Approaches and Targets of Belgium in 2018; European Environment Agency: København, Denmark, 2019.

45. EEA. Resource Efficiency and Circular Economy in Europe-Even More from Less. An Overview of Policies, Approaches and Targets of The Netherlands in 2018; European Environment Agency: København, Denmark, 2019.

46. European Union. Directive 94/62/EC on packaging and packaging waste. In 94/62/EC; European Union: Brussels, Belgium, 1994.

47. European Union. Directive 1999/31/EC on the landfill of waste. In 1999/31/EC; European Union: Brussels, Belgium, 1999.

48. European Union. Directive 2000/76/EC on the incineration of waste. In 2000/76/EC; European Union: Brussels, Belgium, 2000.

49. European Union. Directive 2008/98/EC on waste and repealing certain Directives. In 2008/98/EC; European Union: Brussels, Belgium, 2008.

50. Malinauskaite, J.; Jouhara, H.; Czajczynska, D.; Stanchev, P.; Katsou, E.; Rostkowski, P.; Thorne, R.; Colón, J.; Ponsá, S.; Al-Mansour, F.; et al. Municipal solid waste management and waste-to-energy in the context of a circular economy and energy recycling in Europe. Energy 2017, 141, 2013-2044. [CrossRef]

51. Scarlat, N.; Fahl, F.; Dallemand, J.-F. Status and opportunities for energy recovery from municipal solid waste in Europe. Waste Biomass-Valorization 2018, 10, 2425-2444. [CrossRef]

52. European Union. Directive 2018/851 amending Directive 2008/98/EC on waste. In 2018/851; European Union: Brussels, Belgium, 2018.

53. COM. Communication on the European Green Deal; COM: Brussels, Belgium, 2019.

54. OVAM. 30 jaar OVAM-De Openbare Vlaamse Afvalstoffenmaatschappij in Historisch Perspectief; Academia Press: Gent, Belgium, 2011.

55. Drift. Staat van Transitie: Dynamiek in Mobiliteit, Klimaatadaptatie en Circulaire Economie; Drift: Rotterdam, The Netherlands, 2019.

56. European Union. Directive 75/442/EEC on waste. In 75/442/EEC; European Union: Brussels, Belgium, 1975.

57. Vlaamse Overheid. Afvalstoffendecreet; Vlaamse Overheid: Brussels, Belgium, 1981.

58. OVAM. Huishoudelijk afval en Gelijkaardig Bedrijfsafval 2018; OVAM: Mechelen, Belgium, 2019.

59. OVAM. Uitvoeringsplan Huishoudelijk Afval en Gelijkaardig Bedrijfsafval; OVAM: Mechelen, Belgium, 2019.

60. COM. Basel Convention on the control of transboundary movements of hazardous wastes and their disposal. In 93/98/EEC; Council, E., Ed.; European Commission: Brussels, Belgium, 1993.

61. OVAM. Bedrijfsafvalstoffen Productiejaar 2004-2016; OVAM: Mechelen, Belgium, 2018.

62. OVAM. Tarieven en Capaciteiten Voor Storten en Verbranden. Actualisatie tot 2017; OVAM: Mechelen, Belgium, 2018.

63. NSP. Duurzaamheidsambitie 2030—Duurzaamheid werkt verder; North Sea Port: Ghent, Belgium, 2016.

64. Stad Gent. Lokaal en sociaal. Naar een Gentse Circulaire Economie; Stad Gent: Ghent, Belgium, 2018.

65. Stad Gent. Samen Circulair. Potentieel voor economie en werkgelegenheid in Gent; Stad Gent: Ghent, Belgium, 2018.

66. NSP. Onderzoek Clean Undergroudn Sustainable Transport (CUST); North Sea Port: Ghent, Belgium, 2019.

67. Loorbach, D. Transition Management. New Mode of Governance for Sustainable Development; Erasmus University Rotterdam: Rotterdam, The Netherlands, 2007.

68. Meadows, D.H.; Meadows, D.L.; Randers, J.; Behrens, W.W. The Limits to Growth. A Report for the Club of Rome's Project on the Predicament of Mankind; Universe Books: New York, NY, USA, 1972.

69. CBS. Nauwelijks meer afval, beter gescheiden; Centraal bureau voor de statistiek: CBS: The Hague, The Netherlands, 2019.

70. RWS. Afvalmonitor; Rijkswaterstaat: Utrecht, The Netherlands, 2020. 
71. CE Delft. Verbranden in Nederland of stroten in Groot-Brittannie? Milieukundige analyse van de verwerking van brits huishoudelijk afval in Nederland; CE Delft: Delft, The Netherlands, 2012.

72. Gemeente Amsterdam. Amsterdam Circulair 2020-2025 Strategie; Gemeente Amsterdam: Amsterdam, The Netherlands, 2020.

73. Gemeente Amsterdam. Amsterdam Circulair. Een visie en routekaart voor de stad en regio; Gemeente Amsterdam: Amsterdam, The Netherlands, 2015.

74. Amsterdam Port Authority. Jaarverslag 2015; Amsterdam Port Authority: Amsterdam, The Netherlands, 2016.

75. Van den Berghe, K. Planning the Port City. A Contribution to and Application of the Relational Approach, Based on Five Case Studies in Amsterdam (The Netherlands) and Ghent (Belgium); Ghent University: Ghent, Belgium, 2018.

76. Wiegmans, B.; Louw, E. Changing port-city relations at Amsterdam: A new phase at the interface? J. Transp. Geogr. 2011, 19, 575-583. [CrossRef]

77. Hoppe, T.; Van Bueren, E. Guest editorial: Governing the challenges of climate change and energy transition in cities. Energy Sustain. Soc. 2015, 5. [CrossRef]

78. European Union. Directive 2001/77/EC on the promotion of electricity produced from renewable energy sources in the internal electricity market. In 2001/77/EC; European Union: Brussels, Belgium, 2001.

79. Boffey, D. Amsterdam to embrace 'doughnut' model to mend post-coronavirus economy. The Guardian, 8 April 2020.

(C) 2020 by the authors. Licensee MDPI, Basel, Switzerland. This article is an open access article distributed under the terms and conditions of the Creative Commons Attribution (CC BY) license (http://creativecommons.org/licenses/by/4.0/). 